\title{
Komunitas Serangga pada Tanaman Orok-Orok (Crotalaria Striata) di Berbagai Habitat
}

\author{
HASMIANDY HAMID ${ }^{1), 3)}$, DAMAYANTI BUCHORI ${ }^{2 \text {, }}$, SYAFRIDA \\ MANUWOTO $^{2)}$, dan HERMANU TRIWIDODO ${ }^{2)}$ \\ ${ }^{1)}$ Jurusan Hama dan Penyakit Tumbuhan, Faperta, Universitas Andalas, Kampus Limau Manih, \\ Padang 25163. ${ }^{2}$ Departemen Proteksi Tanaman, Faperta, Institut Pertanian Bogor, Kampus \\ Dramaga, Bogor $16680 .{ }^{35}$ Penulis untuk korespondensi, Tel.+628158212903. \\ E-mail : hasmiandyhamid@yahoo.com
}

(diterima Januari 2007, disetujui Juni 2007)

\begin{abstract}
Insect Community at Orok-orok Plantation (Crotalaria striata) from Different Habitat. Hasmiandy Hamid, Damayanti Buchori, Sjafrida Manuwoto, dan Hermanu Triwidodo. To study insect community at orok-orok plantation (Crotalaria striata) from different habitat, we observed insects that interacted with Crotalaria plantation. There were four habitat type that used in this research, habitat open area and others were agroforestry habitat. We counted about nine ordo from insect that interacted with Crotalaria plant. More than $70 \%$ member of ordo, include to Hymenoptera, specially Formicidae. Not all function member of the ordo that known, but some of them are pollinator, parasitoid, predator and herbivore.
\end{abstract}

KEYWORDS: Insect community, habitat type, Crotalaria

\section{PENDAHULUAN}

Crotalaria merupakan genus dari tanaman herba dan semak berkayu dalam famili Fabaceae (Subfamili Faboideae) yang umumnya dikenal sebagai rattlepods. Sekitar 600 atau lebih spesies Crotalaria dideskripsikan di seluruh dunia dan kebanyakan dari daerah tropis, sekurang-kurangnya 500 spesies diketahui dari Afrika (Wikipedia 2007). Di Jawa, dilaporkan terdapat 32 jenis Crotalaria. Jenisjenis tersebut masuk ke Indonesia dari berbagai negara asal, misalnya $C$. incana atau orok-orok kebo berasal dari Amerika tropika, C. usaramoensis dari Afrika tropika, dan lain-lain. Daun beberapa jenis Crotalaria merupakan pupuk hijau. Jenis-jenis yang demikian sudah lama dibudidayakan. Selain jenis yang bermanfaat, banyak juga Crotalaria yang tumbuh liar seperti di semak-semak, padang rumput, padang alang-alang, pinggiran jalan dan tempat-tempat liar lainnya. Tumbuhan ini menyukai tempat-tempat terbuka (Sastrapradja \& Afriastini 1984).

Penelitian mengenai tumbuhan legum khususnya Crotalaria sp. telah dilakukan meskipun jumlahnya tidak terlalu banyak. Niang et al. (2002) 
mengemukakan bahwa beberapa jenis tumbuhan legum, termasuk Crotalaria merupakan jenis yang dapat digunakan sebagai tanaman yang dapat meningkatkan kesuburan pada tanah. Penelitian mengenai Crotalaria juga dilakukan oleh Mangundojo (1958) di Jawa. Penelitian tersebut berkaitan dengan komunitas serangga pada polong Crotalaria khususnya Crotalaria juncea L., sedangkan Hamid (2008) meneliti mengenai komunitas serangga pada polong Crotalaria striata pada ketinggian tempat dan tipe habitat yang berbeda. Selain itu Crotalaria dapat juga digunakan untuk meneliti mengenai pola kekayaan spesies serangga baik herbivora maupun parasitoid pada polong legum seperti penelitian yang dilakukan oleh Dolch (2000).

Berdasarkan hal tersebut, penelitian ini bertujuan untuk mempelajari komunitas serangga yang berinteraksi dengan tanaman $C$. striata. Hal ini sangat penting dilakukan agar kita dapat mengetahui interaksi yang terjadi antara tanaman Crotalaria yang merupakan tanaman eksotik dengan berbagai jenis serangga baik yang bermanfaat ataupun tidak. Informasi ini sangat berguna untuk memberikan pemahaman yang mendasar mengenai persoalan introduksi spesies baru yang dapat menimbulkan dampak yang tidak diinginkan ataupun yang menguntungkan. Informasi tersebut secara keseluruhan merupakan landasan yang penting dalam usaha konservasi keanekaragaman hayati, khususnya serangga.

\section{BAHAN DAN METODE}

\section{Waktu dan Lokasi Penelitian}

Penelitian ini dilaksanakan mulai Juni sampai Oktober 2005 di desa Toro, Kecamatan Kulawi, Kabupaten Donggala, Sulawesi Tengah yang berjarak sekitar $92 \mathrm{~km}$ dari Palu $(700 \mathrm{~m} \mathrm{dpl})$. Habitat yang digunakan dalam penelitian ini terdiri dari empat habitat yaitu sistem agroforestri (tanaman coklat sebagai tanaman utama) dengan pohon hutan alami yang tersisa sebagai pohon pelindung (D), sistem agroforestri yang dinaungi oleh berbagai tanaman, baik yang ditanam maupun tanaman yang tumbuh secara alami (E), sistem agro-forestri dengan pohon pelindung yang didominasi oleh satu spesies pohon (Erythrina) (F) dan habitat pada daerah terbuka yang terdiri dari lahan yang tidak diolah atau ditanami (G). Pada setiap habitat digunakan empat lokasi yang berbeda. Pemilihan habitat ini didasarkan pertimbangan bahwa tanaman Crotalaria secara umum dapat dijumpai pada sistem agroforestri dan daerah terbuka karena pada habitat tersebut terdapat intensitas penyinaran sinar matahari yang cukup bagi tumbuhan ini untuk tumbuh dan berkembang. Pembuatan plot tanaman Crotalaria dilakukan pada setiap 
habitat tersebut dengan ukuran plot 2 $\mathrm{m} \times 2 \mathrm{~m}$ dengan jarak tanaman $50 \mathrm{~cm}$ sehingga di dalam plot terdapat 16 tanaman.

\section{Metode Penelitian}

Untuk melihat jenis serangga yang berinteraksi dengan tanaman Crotalaria striata pada habitat yang berbeda, diadakan pengamatan secara langsung setiap jenis serangga yang ditemukan berada pada tanaman Crotalaria pada setiap plot (Bestelmeyer et al. 2000; Delabie $e t$ al. 2000; Hashimoto et al. 2001). Jumlah tanaman yang diamati pada setiap plot adalah lima tanaman. Lama pengamatan untuk satu tanaman berkisar 5-10 menit. Pengamatan dilakukan pada saat tanaman mulai memasuki awal masa generatif (membentuk bunga dan buah) dan berakhir ketika tanaman masuk ke masa generatif akhir. Selang waktu antara pengamatan adalah dua minggu, kecuali antara pegamatan satu dan dua serta tujuh dan delapan yang berselang empat minggu. Setiap jenis serangga yang ditemukan pada tanaman, dicatat jenis dan jumlahnya..

Jenis serangga yang sama pada satu plot hanya dikoleksi beberapa individu saja. Serangga yang dikoleksi dimasukkan dalam microtube yang berisi alkohol $70 \%$ dan diberi label. Serangga yang ditemukan pada tanaman Crotalaria tersebut selanjutnya diidentifikasi sampai ke tingkat famili, genus atau spesies tergantung pada ketersediaan kunci identifikasi serangga, sedangkan serangga yang tidak teridentifikasi selanjutnya dikelompokkan ke dalam morfospesies (dianggap sebagai spesies).

\section{Analisis data}

Untuk menyelidiki kelimpahan individu formicidae pada waktu pengamatan yang berbeda digunakan pengukuran ANOVA yang berulang (repeated measures ANOVA). Pengujian dari perbedaan antara waktu pengamatan dilakukan dengan menggunakan uji Tukey's HSD $(\alpha=0,05)$. Semua analisis yang dilakukan menggunakan perangkat lunak Statistica for Window's 6.0 ( ${ }^{\circ}$ StatSoft Corp.).

\section{HASIL}

Hasil pengamatan terhadap serangga yang berinteraksi dengan Crotalaria striata dan peranan masing-masing serangga serta kelimpahannya dapat dilihat pada Tabel 1. Dari tabel tersebut terlihat bahwa serangga yang berinteraksi dengan tanaman Crotalaria terdiri dari beberapa ordo dari golongan Hymenoptera, Coleoptera, Diptera, Lepidoptera dan beberapa ordo kecil lainnya seperti Hemiptera, Orthoptera, Dermaptera, Blattodea dan Ephemeroptera. Dari sejumlah ordo tersebut, ordo Hymenoptera merupakan ordo yang dominan baik pada habitat D (81\%), habitat E (92\%), 
Tabel 1. Beberapa ordo serangga yang ditemukan berhubungan dengan tanaman Crotalaria striata dan peranan masing-masing serangga serta kelimpahannya pada beberapa tipe habitat

\begin{tabular}{|c|c|c|c|c|c|c|c|c|}
\hline \multirow{2}{*}{ Ordo } & \multirow{2}{*}{ Famili } & \multirow{2}{*}{ Species } & \multirow{2}{*}{ Peranan } & \multicolumn{4}{|c|}{ Habitat } & \multirow{2}{*}{ Total } \\
\hline & & & & $D^{2}$ & $\mathrm{E}^{b}$ & $F^{\circ}$ & $\mathrm{G}^{d}$ & \\
\hline Blattodea & Blattidae & Periplanetta sp. & $\begin{array}{l}\text { tidak } \\
\text { diketahui }\end{array}$ & & 2 & 18 & 13 & 33 \\
\hline \multirow[t]{23}{*}{ Colepotera } & Antribiidae & $\begin{array}{l}\text { Eucornutus } \\
\text { crassicornis }\end{array}$ & Herbivora & 21 & 23 & 15 & 101 & 160 \\
\hline & Cerambycidae & sp. & Herbivora & 0 & & 2 & 1 & 3 \\
\hline & Chrysomelidae & Altica sp. & Herbivora & 3 & & 1 & 1 & 5 \\
\hline & Chrysomelidae & Menolepta sp. & Herbivora & 2 & 6 & 1 & & 9 \\
\hline & Coccinellidae & sp. & Herbivora & & & 2 & 3 & 5 \\
\hline & Curculionidae & sp.1 & $\begin{array}{l}\text { tidak } \\
\text { diketahui }\end{array}$ & & 2 & 19 & 69 & 90 \\
\hline & Curculionidae & sp. 2 & $\begin{array}{l}\text { tidak } \\
\text { diketahui }\end{array}$ & & 2 & 2 & 10 & 14 \\
\hline & Curculionidac & sp. 3 & $\begin{array}{l}\text { tidak } \\
\text { diketahui }\end{array}$ & & & 2 & 7 & 9 \\
\hline & Curculionidae & sp. 4 & $\begin{array}{l}\text { tidak } \\
\text { diketahui }\end{array}$ & 4 & & 5 & 1 & 10 \\
\hline & Curculionidae & sp. 5 & $\begin{array}{l}\text { tidak } \\
\text { diketahui }\end{array}$ & & 2 & 3 & & 5 \\
\hline & Elateridae & sp. & Herbivora & & & & 1 & 1 \\
\hline & Languriidae & sp. & Herbivora & & 2 & 3 & 1 & 6 \\
\hline & Nitidulidae & Epurea sp. & Herbivora & & 1 & & 3 & 4 \\
\hline & Rhizophagidae & sp.1 & Herbivora & & & & 25 & 25 \\
\hline & Rhizophagidac & sp. 2 & Herbivora & 1 & 1 & 1 & 10 & 13 \\
\hline & Rhizophagidae & sp. 3 & Herbivora & & & 1 & 4 & 5 \\
\hline & Silvanidae & sp. & Herbivora & 1 & 8 & 2 & 10 & 21 \\
\hline & Tenebrionidac & sp.1 & Herbivora & 1 & & & & 1 \\
\hline & Tenebrionidae & $\mathrm{sp} .2$ & Herbivora & & & 4 & & 4 \\
\hline & Tenebrionidae & sp. 3 & Herbivora & & 1 & 3 & 1 & 5 \\
\hline & Tenebrionidae & sp. 4 & Herbivora & & & & 1 & 1 \\
\hline & tidak diketahui & sp.1 & Herbivora & & & 1 & 1 & 2 \\
\hline & tidak diketahui & sp. 2 & Herbivora & & & 1 & & 1 \\
\hline \multirow[t]{8}{*}{ Colepotera } & tidak diketahui & sp. 3 & Herbivora & & & & 2 & 2 \\
\hline & tidak diketahui & sp.4 & Herbivora & & & & 1 & 1 \\
\hline & tidak diketahui & sp. 5 & Herbivora & & & & 1 & 1 \\
\hline & tidak diketahui & sp. 6 & Herbivora & & & 2 & & 2 \\
\hline & tidak diketahui & sp.7 & Herbivora & & 1 & & & 1 \\
\hline & tidak diketahui & $5 p .8$ & Herbivora & 1 & & & & 1 \\
\hline & tidak diketahui & sp.9 & Herbivora & & & & 2 & 2 \\
\hline & tidak diketahui & sp. 10 & Herbivora & & 1 & 1 & & 2 \\
\hline \multirow[t]{2}{*}{ Dermaptera } & Forficulidae & sp. & Predator & 17 & 2 & 5 & 3 & 27 \\
\hline & tidak diketahui & sp. & Predator & 9 & 3 & 5 & 2 & 19 \\
\hline \multicolumn{9}{|c|}{$\begin{array}{l}\text { sistem agroforestri (didominasi oleh kakao) dengan pohon hutan alami yang tersisa sebagai pohon } \\
\text { pelindung. Penutupan kanopi: } 20-50 \% \text {. Intensitas pengelolaan rendah } \\
\text { sistem agroforestri (didominasi oleh kakao) yang dinaungi oleh berbagai tanaman, baik yang ditanam } \\
\text { maupun tanaman yang tumbuh secara alami. Penutupan kanopi: } 20-50 \% \\
\text { 'sistem agroforestri dengan pohon pelindung yang didominasi (lebih dari } 90 \% \text { ) oleh satu spesies pohon } \\
\text { (Erythrina). Penutupan kanopi: } 20-50 \% \\
\text { daerah terbuka, habitat yang terdiri dari lahan yang tidak diolah atau ditanami, tanpa adanya penutupan } \\
\text { kanopi (intensitas matahari } 100 \% \text { ) }\end{array}$} \\
\hline
\end{tabular}


Lanjutan Tabel 1.

\begin{tabular}{|c|c|c|c|c|c|c|c|c|}
\hline \multirow{2}{*}{ Ordo } & \multirow{2}{*}{ Famili } & \multirow{2}{*}{ Species } & \multirow{2}{*}{ Peranan } & \multicolumn{4}{|c|}{ Habitat } & \multirow{2}{*}{ Total } \\
\hline & & & & $\mathrm{D}^{2}$ & $E^{b}$ & $\mathrm{~F}^{2}$ & $G^{d}$ & \\
\hline \multirow[t]{15}{*}{ Diptera } & Asilidac & sp. & tidak diketahui & & & 1 & & 1 \\
\hline & Culicidac & sp. & tidak diketahui & 7 & 2 & 6 & & 15 \\
\hline & Muscidae & sp. & tidak diketahui & 1 & 3 & 1 & 5 & 10 \\
\hline & Syrphidae & sp. & Predator & 2 & 1 & 3 & 3 & 9 \\
\hline & Tipulidae & sp. & tidak diketahui & & & 1 & & 1 \\
\hline & tidak diketahui & sp. 1 & tidak diketahui & 1 & & & 1 & 2 \\
\hline & tidak diketahui & $\mathrm{sp} .2$ & tidak diketahui & & & 3 & & 3 \\
\hline & tidak diketahui & $s p-3$ & tidak diketahui & 1 & & & & 1 \\
\hline & tidak diketahui & sp. 4 & tidak diketahui & & 2 & & & 2 \\
\hline & tidak diketahui & 5p. 5 & tidak diketahui & & 5 & 23 & 8 & 36 \\
\hline & tidak diketahui & sp. 6 & tidak diketahui & & & 1 & & 1 \\
\hline & tidak diketahui & sp. 7 & tidak diketahui & 2 & 2 & 8 & 11 & 23 \\
\hline & tidak diketahui & sp. 8 & tidak diketahui & & & 2 & & 2 \\
\hline & tidak diketuhui & sp.9 9 & tidak diketahui & 2 & 5 & & & 7 \\
\hline & tidak diketahui & sp. 10 & tidak diketahui & & 2 & 1 & 1 & 4 \\
\hline \multirow[t]{3}{*}{ Diptera } & tidak diketahui & sp.11 & tidak diketahui & 2 & & 5 & 5 & 12 \\
\hline & tidak diketahui & sp. 12 & tidak diketahui & 2 & 6 & 5 & 3 & 16 \\
\hline & tidak diketahui & sp. 13 & tidak diketahui & 3 & 7 & 57 & 24 & 91 \\
\hline $\begin{array}{l}\text { Ephe- } \\
\text { merop- } \\
\text { tera }\end{array}$ & tidak diketahui & $\mathrm{sp}$. & tidak diketahui & 1 & & & 1 & 2 \\
\hline \multirow[t]{14}{*}{$\begin{array}{l}\text { Hemip- } \\
\text { tera }\end{array}$} & Alydidae & $\mathrm{sp}$. & Herbivora & 10 & 11 & 31 & 52 & 104 \\
\hline & Cicadellidae & $5 p .1$ & Herbivora & & & 1 & & 1 \\
\hline & Cicadellidae & sp. 2 & Herbivora & 1 & 1 & & 1 & 3 \\
\hline & Cicadellidae & sp. 3 & Herbivora & & & 2 & & 2 \\
\hline & Lygaeidae & sp. & Herbivora & 13 & 23 & 90 & 11 & 137 \\
\hline & Membracidae & sp. & Herbivora & 10 & 8 & 19 & 5 & 42 \\
\hline & Pentatomidac & Asopinac sp. 1 & Herbivora & & 2 & & & 2 \\
\hline & Rhopalidae & sp. & Herbivora & & & & 4 & 4 \\
\hline & Pyrrhocoridae & Dysdercus sp. & Herbivora & & 1 & & & 1 \\
\hline & Miridae & Helopeltis sp. & Herbivora & & 1 & & & 1 \\
\hline & Reduviidae & Sycanus sp. & Predator & & & & 1 & 1 \\
\hline & tidak diketahui & sp.1 & Herbivora & & & & 2 & 2 \\
\hline & tidak diketahui & sp. 2 & Herbivora & 1 & & 2 & 1 & 4 \\
\hline & tidak diketahui & sp. 3 & Herbivora & 1 & & & & 1 \\
\hline \multirow[t]{7}{*}{$\begin{array}{l}\text { Hymen- } \\
\text { optera }\end{array}$} & Formicidae & $\begin{array}{l}\text { Anoplolepis } \\
\text { gracilipes }\end{array}$ & Predator & 55 & 65 & 1298 & 855 & 2273 \\
\hline & Formicidac & $\begin{array}{l}\text { Camponotus } \\
\text { sp.1 }\end{array}$ & Predator & 2 & 237 & & 234 & +73 \\
\hline & Formicidae & $\begin{array}{l}\text { Camponotus } \\
\text { sp. } 2\end{array}$ & Predator & 1 & & & & i \\
\hline & Formicidac & $\begin{array}{l}\text { Camponotus } \\
\text { sp. } 4\end{array}$ & Predator & & & & 51 & 51 \\
\hline & Formicidat & $\begin{array}{l}\text { Crematogaster } \\
\text { sp. } 1\end{array}$ & Predator & 430 & 573 & & 125 & 1128 \\
\hline & Formicidac & $\begin{array}{l}\text { Dolichoderus } \\
\text { thoracicus }\end{array}$ & Predator & 5 & 53 & 4 & 17 & 79 \\
\hline & Formicidac & $\begin{array}{l}\text { Monomorium } \\
\text { sp.1 }\end{array}$ & Predator & 20 & 6 & 10 & & 36 \\
\hline
\end{tabular}


Lanjutan Tabel 1.

\begin{tabular}{|c|c|c|c|c|c|c|c|c|}
\hline \multirow{2}{*}{ Ordo } & \multirow{2}{*}{ Famili } & \multirow{2}{*}{ Species } & \multirow{2}{*}{ Peranan } & \multicolumn{4}{|c|}{ Habitat } & \multirow{2}{*}{ Total } \\
\hline & & & & $\mathrm{D}^{\prime}$ & $E^{2}$ & $F^{*}$ & $G^{4}$ & \\
\hline \multirow[t]{20}{*}{ Hymenoptera } & Formicidae & $\begin{array}{l}\text { Odontomachus } \\
\text { sp.1 }\end{array}$ & Predator & & & 1 & & 1 \\
\hline & Formicidac & Paratrechina sp. 1 & Predator & 87 & 759 & 6 & 43 & 895 \\
\hline & Formicidac & Paratrechina sp. 2 & Predator & & 115 & 12 & 12 & 139 \\
\hline & Formicidae & Pobyrachis sp.1 & Predator & 22 & 22 & 2 & 6 & 52 \\
\hline & Formicidac & $\begin{array}{l}\text { Technomyrmex } \\
\text { sp.1 }\end{array}$ & Predator & & & & 5 & 5 \\
\hline & Formicidae & Tetramorium sp.1 & Predator & & & 9 & & 9 \\
\hline & Chalcididae & sp. & Parasitoid & 1 & 3 & 22 & 44 & 70 \\
\hline & Eurytomidac & Eurytoma sp. & Parasitoid & . & & 1 & & 1 \\
\hline & Ichneumonidac & sp.1 & Parasitoid & & 1 & 1 & & 2 \\
\hline & Ichneumonidac & $\mathrm{sp} .2$ & Parasitoid & 1 & & 1 & 1 & 3 \\
\hline & Ichncumonidae & sp. 3 & Parasitoid & & 1 & & & 1 \\
\hline & Pteromalidae & Apsilocera sp. & Parasitoid & 2 & & & 2 & 4 \\
\hline & Torymidae & sp. & Parasitoid & & & & 1 & 1 \\
\hline & Vespidac & sp. & Parasitoid & & & & 1 & 1 \\
\hline & Eupelmidae & sp. & Parasitoid & & & & 1 & 1 \\
\hline & tidak diketahui & sp.1 & Parasitoid & 2 & & & & 2 \\
\hline & tidak diketahui & sp. 2 & Polinator & & 6 & 3 & 5 & 14 \\
\hline & tidak diketahui & $\operatorname{sp} 3$ & Polinator & & 1 & & & 1 \\
\hline & tidak diketahui & sp. 4 & Polinator & & & & 1 & 1 \\
\hline & tidak diketahui & sp. 5 & Parasitoid & & & 1 & & 1 \\
\hline \multirow[t]{5}{*}{ Lepidoptera } & Arctiidae & sp.1 & Herbivora & 1 & 3 & 60 & 1 & 65 \\
\hline & Arctiidae & $\operatorname{sp} .2$ & Herbivora & & & 1 & & 1 \\
\hline & Arctiidae & sp. 3 & Herbivora & & & & 1 & 1 \\
\hline & Arctiidae & sp.4 & Herbivora & 2 & & 1 & & 3 \\
\hline & Arctiidac & sp. 5 & Herbivora & 1 & & & & 1 \\
\hline \multirow[t]{15}{*}{ Lepidoptera } & Arctiidac & sp. 6 & Herbivora & 1 & 3 & & & 4 \\
\hline & Hesperidac & sp. & Herbivora & & & 1 & & 1 \\
\hline & Lycaenidae & $\begin{array}{l}\text { Lampides } \\
\text { boeticus }\end{array}$ & Herbivora & & & & 1 & 1 \\
\hline & Noctuidac & Spodoptera sp. & Hetbivora & & 1 & & & 1 \\
\hline & Noctuidae & sp. 1 & Herbivora & & & & 1 & 1 \\
\hline & Noctuidac & $s p .2$ & Herbivora & 1 & 4 & 3 & & 8 \\
\hline & Noctuidae & sp. 3 & Herbivora & & & 1 & & 1 \\
\hline & Noctuidae & sp. 4 & Herbivora & & 1 & 1 & 1 & 3 \\
\hline & tidak diketahui & sp.1 & Herbivora & & 1 & & & 1 \\
\hline & tidak diketahui & sp. 2 & Herbivora & & & & 1 & 1 \\
\hline & tidak diketahui & sp. 3 & Herbivora & & & & 7 & 7 \\
\hline & tidak diketahui & sp. 4 & Herbivora & & & & 1 & 1 \\
\hline & tidak diketahui & sp. 5 & Herbivora & 11 & 6 & 3 & 1 & 21 \\
\hline & tidak diketahui & sp. 6 & Herbivora & & & & 1 & 1 \\
\hline & tidak diketahui & sp. 7 & Herbivora & 1 & 3 & & 1 & 5 \\
\hline \multirow[t]{3}{*}{ Orthoptera } & Acrididae & Valanga sp. & Herbivora & 6 & 13 & 7 & 3 & 29 \\
\hline & Gryllidae sp. & Gryllus sp. & Herbivora & 1 & 5 & 4 & 5 & 15 \\
\hline & Tettigoniidae & Mecopoda sp. & Herbivora & 12 & 12 & 25 & 25 & 74 \\
\hline Total & & & & 785 & 2033 & 1839 & 1867 & 6524 \\
\hline
\end{tabular}


habitat $\mathrm{F}(74 \%)$ maupun habitat $\mathrm{G}$ (75\%). Selain Hymenoptera, ordo Coleoptera juga merupakan ordo yang jumlah individunya relatif lebih berlimpah dibandingkan ordo lainnya pada habitat tersebut. (Gambar 1). Jika dilihat dari peranan serangga pada Crotalaria, sebagian besar individu ordo Hymenoptera, yaitu semut berperanan sebagai predator. sedangkan anggota lainnya berperanan sebagai polinator ataupun parasitoid.
Untuk ordo serangga lain, sebagian besar berfungsi sebagai herbivora, seperti pada ordo Lepidoptera, Coleoptera dan Orthoptera, sedangkan beberapa ordo lain seperti Hemiptera meskipun sebagian besar anggotanya berperanan sebagai herbivora, namun ada juga yang berperanan sebagai predator, seperti Sycanus sp. Beberapa ordo lainnya seperti Diptera, Ephemeroptera, dan Blattodea sebagian besar anggotanya tidak dike-

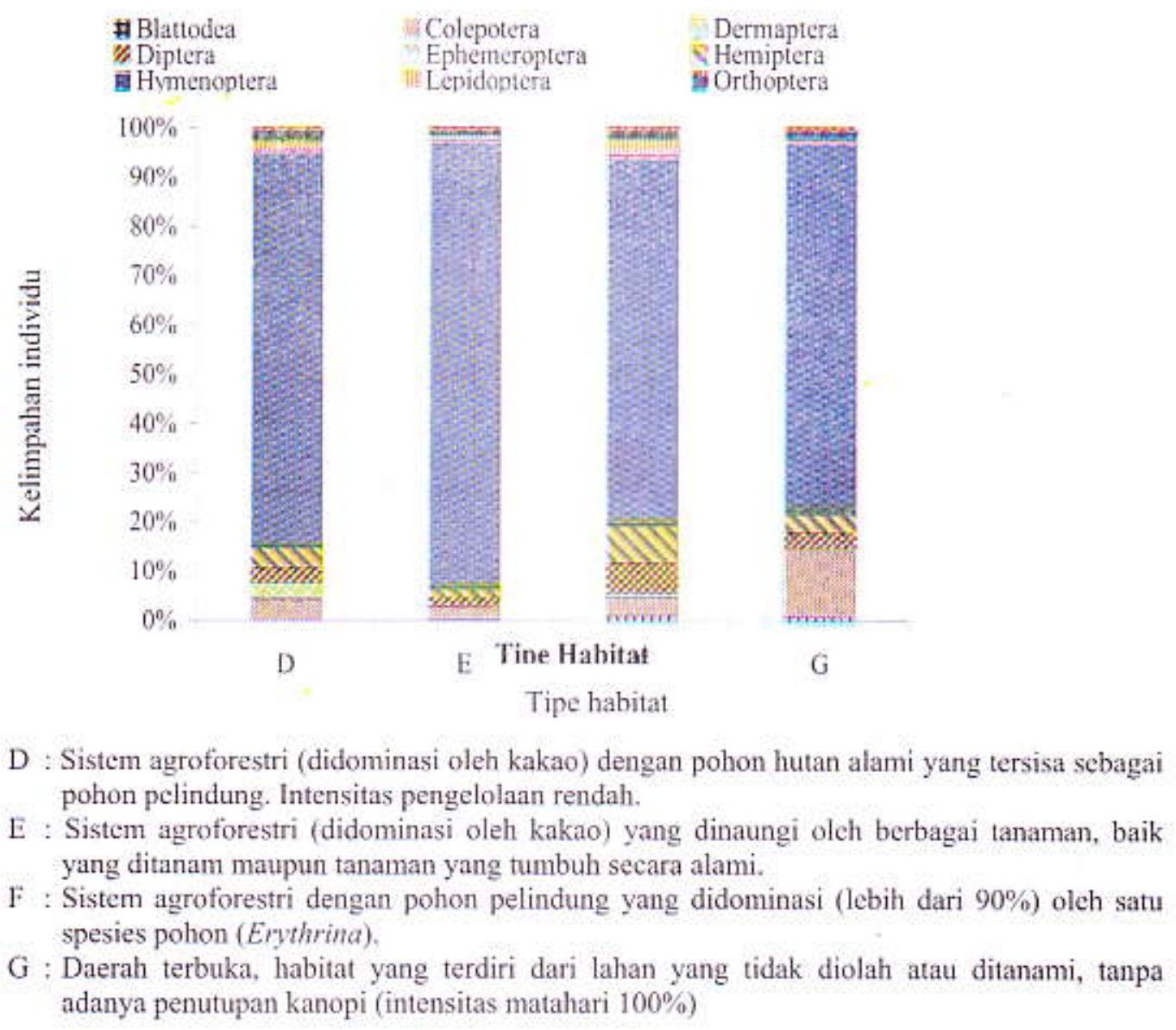

Gambar 1. Kelimpahan individu serangga yang ditemukan berassosiasi dengan tanaman Crotalaria pada beberapa tipe habitat 
tahui peranannya bagi Crotalaria bahkan kelimpahannya lebih besar dari striata, sedangkan untuk Dermaptera total kelimpahan individu seluruh semuanya bertindak sebagai predator. famili lainnya. Pola tersebut dapat Jika dilihat dari kelimpahan ditemukan pada setiap habitat (Gambar individu, maka Formicidae (semut) 2). Keberadaan semut secara umum merupakan famili yang kelimpahan pada pertanaman Crotalaria relatifnya lebih besar dibandingkan mengalami perubahan dari waktu ke dengan famili lain yang ditemukan waktu. Kelimpahan individu semut berinteraksi dengan tanaman C, striata,

DFomicidae GFanili lain

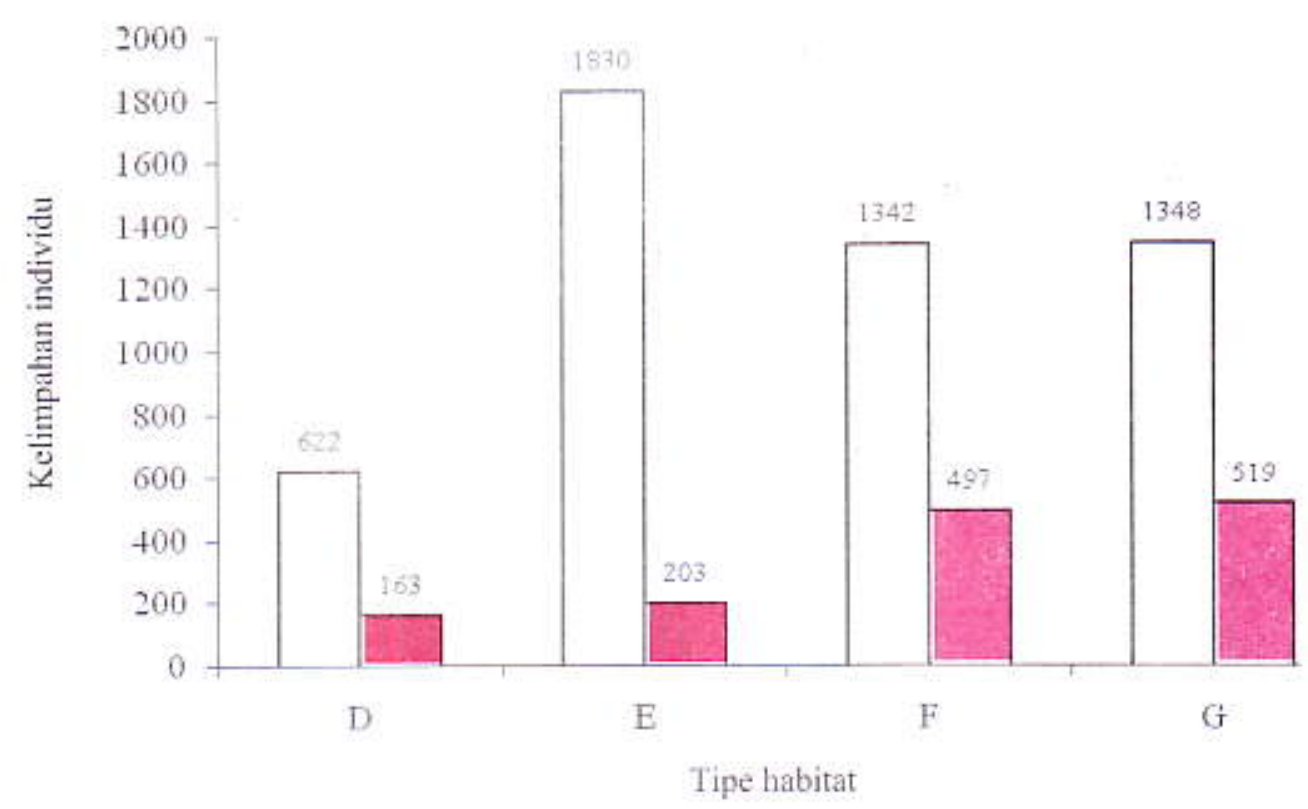

D: Sistem agroforestri (didominasi oletr kakao) dengan pohon hutan alami yang tersisa sebagai pohon pelindung. Intensitas pengelolaan rendab.

E: Sistem agroforestri (didominasi oleh kakao) yang dinaungi oleh berbagai tanaman, baik yang ditanam maupun tanamun yang tumbuh secara alami.

F : Sistem agroforestri dengan pohon pelindung yang didominasi (lebih dari $90 \%$ ) oleh satu spesies pohon (Erythrina).

G: Daerah terbuka, habitat yang terdiri dari lahan yang tidak diolah atau ditanami, tanpa adanya penutupan kanopi (intensitas matahari $100 \%$ )

Gambar 2. Kelimpahan individu dari Famili Formicidae dan Famili lain yang ditemukan berassosiasi dengan tanaman Crotalaria pada beberapa tipe habitat 
cenderung mengalami peningkatan seiring dengan masa generatif tanaman dan mengalami penurunan pada akhir masa generatif (Gambar 3).

\section{PEMBAHASAN}

Keberadaan serangga pada tanaman tidak terlepas dari interaksi yang terjadi antara serangga dan tanaman. Hal ini dapat dilihat dari hasil penelitian yang dilakukan. Berbagai jenis serangga dapat ditemukan berinteraksi dengan Crotalaria yang ditanam pada berbagai habitat. Sebagian besar merupakan ordo Hymenoptera dan beberapa ordo besar lain seperti Coleoptera, Diptera dan Lepidoptera serta beberapa ordo kecil. Sebagian besar anggota dari Hymenop-tera termasuk dalam golongan semut. Hal ini kemungkinan terjadi karena semut merupakan organisme yang mempunyai kemampuan untuk mendo-minasi suatu habitat dengan cepat de-ngan kepadatan yang sangat tinggi. Abbot (2005) mengemukakan bahwa Anoplolepsis gracipes yang merupakan spesies invasif, kepadatannya dapat mencapai 2254 individu per $\mathrm{m}^{2}$ dan merupunyai biomassa 1.85 gram per $\mathrm{m}^{2}$. Selain dari golongan semut, anggota dari Hymenoptera sebagian besar berfungsi sebagai parasitoid atau polinator. Untuk golongan Coleoptera, salah satu jenis yang paling penting adalah Eucorymus crassicornis, karena serangga ini merupakan serangga herbivora utama pada polong tanaman Crotalaria. Selain Eucorynus, jenis

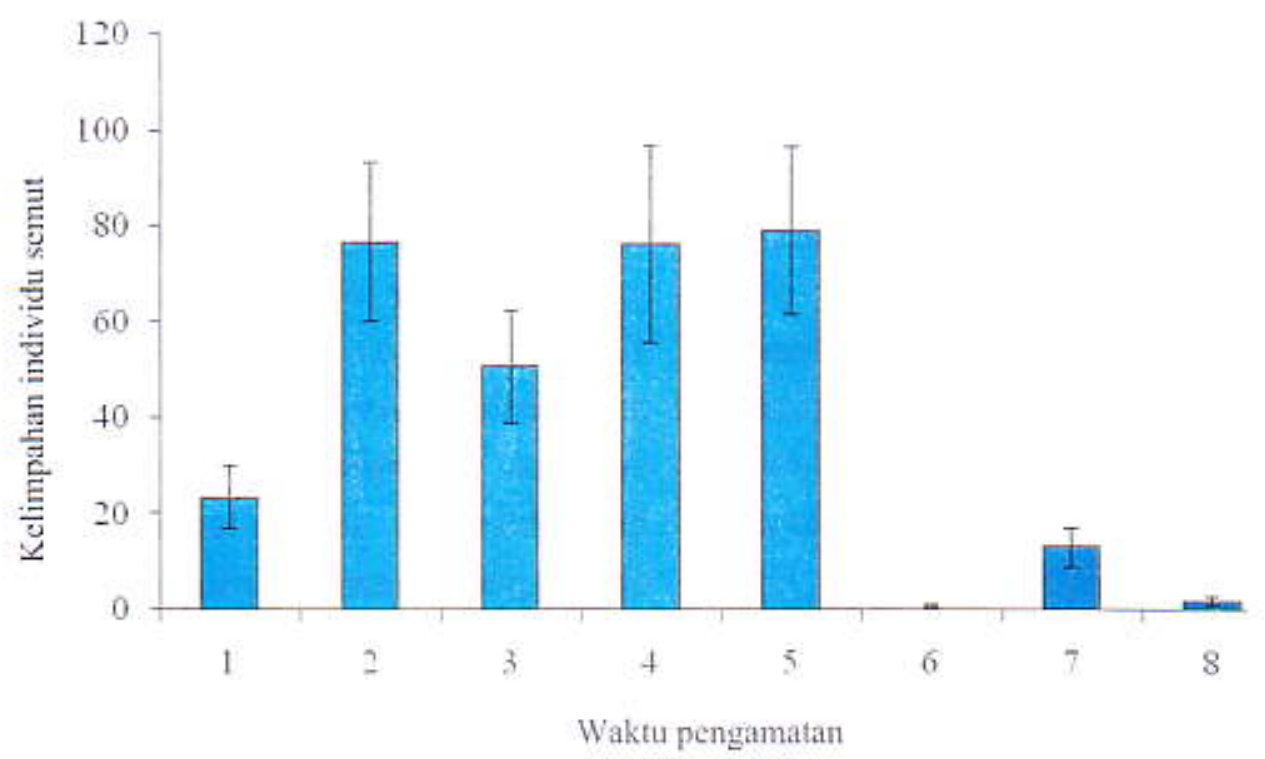

Gambar 3. Kelimpahan individu Famili Formicidae pada waktu pengamatan berbeda yang dimulai ketika tanaman memasuki masa generatif dan selang waktu pengamatan dua minggu, kecuali antara pegamatan satu dan dua serta tujuh dan delapan yang berselang empat minggu. 
serangga lain dari golongan Coleoptera yang banyak ditemukan pada tanaman Crotalaria adalah spesies dari famili Curculionidae sub famili Baridinae. Pada pertanaman, serangga tersebut banyak ditemukan pada bagian bunga tanaman dan juga melakukan kopulasi. Namun demikian, tidak diketahui secara jelas fungsi dari serangga ini karena tidak terlihat dampaknya bagi tanaman. Ordo lain yang ditemukan dan berperanan dalam pertumbuhan dan perkembangan tanaman Crotalaria adalah Orthoptera dan Lepidoptera. Dari pengamatan di lapangan sering sekali serangga dari ordo ini makan pada bagian tanaman seperti daun, batang dan bunga yang bisa berdampak buruk pada perkembangan tanaman walaupun pada penelitian ini dampaknya tidak terlalu besar. Beberapa ordo lain yang juga ditemukan berinteraksi dengan Crotalaria walaupun ada yang berperanan pada tanaman seperti ordo Hemiptera dan Dermaptera yang bertindak sebagai predator namun terdapat juga ordo yang tidak diketahui peranannya, seperti dari golongan Ephemeroptera dan beberapa jenis dari Blattodea dan Diptera. Ordo Dermaptera keberadaannya pada tanaman terutama pada bagian polong dan tersebar pada beberapa lokasi. sedangkan serangga dari golongan Hemiptera yang bertindak sebagai predator, hanya ditemui pada satu lokasi dan bertindak sebagai predator dari Eucorynus. Keberadaan berbagai jenis serangga pada tanaman Crotalaria ini, baik secara langsung ataupun tidak langsung akan berperanan dalam pembentukan komunitas serangga, baik herbivora ataupun parastoid pada polong tanaman ini yang nantinya akan menentukan kemampuan tanaman ini untuk dapat tumbuh dan berkembang.

Dari analisis yang dilakukan terlihat bahwa fenologi tanaman mempengaruhi kelimpahan individu semut yang berinteraksi dengan tanaman $\mathrm{Hal}$ ini diduga dipengaruhi oleh keberadaan bunga dan buah yang dihasilkan oleh tanaman. Pada awal dan akhir masa generatif, jumlah bunga dan buah yang dihasilkan lebih sedikit dibandingkan dengan pada pertengahan masa generatif yang merupakan waktu optimum dalam pembentukan buah dan bunga. Struktur reproduksi tersebut sering dihubungkan dengan adanya extrafloral nectar yang dihasilkan oleh tumbuhan (DiazCastelazo et al. 2005). Keberadaan extrafloral nectar yang dihasilkan oleh tanaman tersebut kemungkinan mengakibatkan semut tertarik untuk datang pada tanaman Crotalaria. Hasil penelitian Diaz-Castelazo \& RicoGray (2004) memperlihatkan bahwa sekitar $66 \%$ dari tanaman yang menghasilkan extrafloral nectar dikunjungi oleh semut. Blüthgen et al. (2000) selanjutnya mengemukakan bahwa extrafloral nectar yang dihasilkan oleh 
tumbuhan merupakan sumber makanan bagi semut. Keberadaan serangga lain yang sering dihubungkan dengan keberadaan semut, yaitu aphis, tidak ditemukan pada tanaman ini. Oleh karena itu, kemungkinan besar extrafloral nectar yang memberikan dampak bagi keberadaan semut pada pertanaman Crotalaria dibandingkan faktor serangga tersebut. Keberadaan semut itu sendiri berkaitan dengan sistem pertahanan tumbuhan terhadap serangga herbivora. Fernandes et al. (2005) mengemukakan bahwa keberadaan semut mengurangi tingkat serangan dari serangga herbivora dan juga dapat merubah struktur komunitas serangga herbivora yang berhubungan dengan tumbuhan.

\section{KESIMPULAN}

Berbagai jenis serangga yang termasuk ke dalam ordo besar serangga seperti Hymenoptera, Coleoptera, Dip-tera, Lepidoptera, Hemiptera dan bebe-rapa ordo kecil lainnya seperti, Blatto-dea, Orthoptera, Dermaptera dan Ephe-meroptera ditemukan berinteraksi de-ngan tanaman Crotalaria. Serangga dari ordo Hymenoptera merupakan serangga yang dominan ditemukan berinteraksi dengan tanaman tersebut, utamanya dari famili Formicidae. Beberapa jenis serangga diketahui berperanan sebagai herbivor, predator, parasitoid dan polinator, namun beberapa jenis belum diketahui peranannya. Keberadaan semut pada tanaman Crotalaria terkait dengan keberadaan struktur generatif tanaman yaitu bunga dan buah yang dapat menghasilkan sumberdaya yang dapat dimanfaatkan oleh semut tersebut. yaitu extrafloral nectar.

\section{UCAPAN TERIMA KASIH}

Ucapan terima kasih disampaikan kepada Wolfram Lorentz, Adam Malik, Surya Tarigan, Rina Yusuf, Arman, Aco, dan semua pengemudi pada Proyek Penelitian Kerjasama Indonesia-Jerman STORMA (Stability of Tropical Rainforest Margins) atas dukungan dan bantuannya. Ucapan yang sama kami sampaikan kepada Pak Said dan Jumadi Pirade yang telah membantu selama penelitian, serta penduduk desa Toro terutama pemilik kebun yang digunakan dalam penelitian ini. Tak lupa ucapan terima kasih kepada Akhmad Rizali dan Boris Bueche yang telah membantu dalam identifikasi beberapa jenis serangga. Penelitian ini merupakan bagian dari penelitian yang didanai oleh Proyek Penelitian Kerjasama Indonesia-Jerman STORMA dan Hibah Penelitian Pascasarjana (Hibah Pasca) Dikti.

\section{DAFTAR PUSTAKA}

Abbott KL. 2005. Supercolonies of the invasive yellow crazy ant, Anoplolepis gracilipes, on an oceanic 
island: Forager activity patterns, density and biomass. Insect. Soc. 52 (2005) 266-273.

Bestelmeyer BT et al. 2000. Field techniques for the study of ground-dwelling ants. Di dalam: Agosti D, Majer JD, Alonso LE, Schultz TR (eds). Ants: standard methods for measuring and monitoring biodiversity. Washington: Smith-sonian Institution Press.

Bluethgen N, Verhaagh M, Goitia W, Jaffé K , Morawetz W, Barthlott W. 2000. How plants shape the ant community in the Amazonian rainforest canopy the key role of extrafloral nectarines and homopteran honeydew. Oecologia 125:229-240.

Delabie JHC, Fisher BL, Majer JD, Wright IW. 2000. Sampling effort and choice and methods. In Agosti D, Majer JD, Alonso LE, Schultz TR (eds). Ants: standard methods for measuring and monitoring biodiversity. Washington: Smithsonian Institution Press.

Diaz-Castelazo C, Rico-Gray V. 2004. Extrafloral nectary-mediated ant-plant interactions in the coastal vegetation of Veracruz, Mexico Richness occurance seasonality and ant foraging patterns. Ecoscience 11(4): $472-481$.

Diaz-Castelazo C, Rico-Gray V, Ortega F, Angeles G. 2005. Morphological and Secretory Characterization of Extrafloral Nectaries in Plants of Coastal Veracruz, Mexico. Ann Bot 96: $1175-1189$.

Dolch R. 2000. Artenreichtum von Herbivoren-ParasitoidenGesellschaften an Leguminosen: Ein Vergleich tropischer und gemäßigter
Breiten [dissertation]. Fachgebiet Agrarökologie Fakultăt für Agrarwissenschaften Georg-AugustUniversităt-Göttingen.

Fernandes GW, Fagundes M. Greco MKB, Barbeitos MS, Santos JC. 2005. Ants and their effects on an insect herbivore community associated with the inflorescences of Byrsonima crassifolia (Linnaeus) H.B.K. (Malpighiaceae). Revista Bras Entomol 49(2): 264-269.

Hashimoto Y, Yamane S, Mohamed M. 2001. How to design an inventory method for ground-level ants in tropical forests. Nat Hum Activ 6: 25-30.

Hamid 2008. Komunitas serangga herbivora penggerek polong legum dan parasitoidnya: Studi kasus di daerah Palu dan Toro, Sulawesi Tengah. [Disertasi]. Bogor: Sekolah Pascasarjana IPB.

Mangundojo RGS. 1958. Penjelidikan mengenai penggerek polong Crotalaria juncea L. di Djawa [Disertasi]. Djakarta: Universitas Indonesia, Fakultas Pertanian.

Niang AI, Amadalo BAA, de Wolf J, Gathumbi SM. 2002. Species screening for shortterm planted fallows in the highlands of western Kenya. Agroforest Syst 56:145-154.

Sastrapradja S, Afriastini JJ. 1984. Polongpolongan perdu. Bogor: Lembaga Ilmu Pengetahuan Indonesia.

Statsoft. 1998. Statistica for Windows Release 6.0. Tulsa: StatSoft.

Wikipedia. 2007.2 Crotalaria. http://en.wikipedia.org/wiki/Crotalari a $\quad\left[\begin{array}{lll}7 & \mathrm{Mei} & 2007\end{array}\right]$. 